\title{
Geotechnical, Mineralogical and Chemical Characterization of the Missole II Clayey Materials of Douala Sub-Basin (Cameroon) for Construction Materials
}

\author{
Elisabeth Olivia Logmo ${ }^{1}$, Gilbert François Ngon $\operatorname{Ngon}^{1 *}$, Williams Samba ${ }^{1}$, \\ Michel Bertrand Mbog $^{2}$, Jacques Etame ${ }^{1}$ \\ ${ }^{1}$ Laboratory of Subsurface, Department of Earth Sciences, Faculty of Science, University of Douala, Douala, Cameroon \\ ${ }^{2}$ Laboratory of Environmental Geology, Department of Earth Sciences, Faculty of Science, University of Dschang, \\ Dschang, Cameroon \\ Email: "gngonngon@yahoo.fr
}

Received May 1, 2013; revised June 3, 2013; accepted June 11, 2013

Copyright (C) 2013 Elisabeth Olivia Logmo et al. This is an open access article distributed under the Creative Commons Attribution License, which permits unrestricted use, distribution, and reproduction in any medium, provided the original work is properly cited.

\begin{abstract}
Geotechnical tests conducted on clayey materials of Missole II, Douala sub-basin of Cameroon showed that these materials present: fines particles (55 to $78 \mathrm{wt} . \%$ ), sand (22 to $44 \mathrm{wt} . \%$ ), and plasticity index of 13.8 to $21.6 \%$. The X-ray diffraction (XRD) and the chemical analysis revealed a kaolinite amount of 46 to $56 \mathrm{wt} . \%, 19$ to $27 \mathrm{wt} . \%$ of illite, 12 to $19 \mathrm{wt} . \%$ of quartz, 3 to $5 \mathrm{wt} . \%$ of goethite, 2 to $5 \mathrm{wt} . \%$ of hematite, 1.5 to $5 \mathrm{wt} . \%$ of anatase, 2 to $3 \mathrm{wt} . \%$ of feldspar-K with 52.87 to 63.11 wt.\% of $\mathrm{SiO}_{2}, 18.08$ to 24.31 wt.\% of $\mathrm{Al}_{2} \mathrm{O}_{3}, 3.28$ to 11.45 wt.\% of $\mathrm{Fe}_{2} \mathrm{O}_{3}$ and a small content of bases $(<2 \mathrm{wt} . \%)$. The results of geotechnical tests combined to those of the XRD and the chemical analysis showed that the Missole II clayey materials are suitable for the manufacture of bricks, tiles and sandstones.
\end{abstract}

Keywords: Cameroon; Construction Materials; Geotechnical Tests; Mineralogical and Chemical Analyses; Missole II

\section{Introduction}

Clay-rich materials are intensively used in the manufacturing of ceramics and as construction materials. However, the clayey deposit types are known as sedimentary, alluvial, and residual. A good knowledge of their occurrences, quantity and properties is required for their efficient exploitation.

In the Douala sedimentary sub-basin (South-Cameroon, Central Africa), some studies are done concerning the stratigraphic and tectonic evolution including [1-13]. Others studies are done to set up industrial units for manufacturing construction materials and ceramics [14] or concerning the mineralogical and chemical or thermal characteristics of the clay sediments [15-21].

In the Missole II area (Douala sub-basin), a geological study is carried out to locate and describe the clayey material outcrops and their provenance [22-24]. Also, some authors showed the possibility to obtain good ceramic building materials by mixing silica, feldspars, and kaolinitic and illitic clay of the Missole II area [25]. However, despite the preliminary works done on the field to

${ }^{*}$ Corresponding author. describe clayey materials and to determine their sedimentation evolution, no further physical, mineralogical and chemical study is carried out to show their characteristics in order to their applications.

To that effect, the objective of this study is to associate the geotechnical characteristic to the mineralogical and chemical compositions of the clay occurrences of the Missole II deposit in order to evaluate its suitability for manufacturing of construction materials and ceramics.

\section{Geographic and Geological Setting}

Missole II is located on the Eastern part of the Douala sub-basin (Cameroon, Central Africa) between latitude $3^{\circ} 59^{\prime}-3^{\circ} 54^{\prime} \mathrm{N}$ and longitude $9^{\circ} 54^{\prime}-9^{\circ} 58^{\prime} \mathrm{E}$. It is located within a humid equatorial climatic zone. Annual rainfall ranges between 3000 and $5000 \mathrm{~mm}$, and the annual average temperature is $26^{\circ} \mathrm{C}$. The vegetation is a dense rainforest transformed by human activities [26]. The geomorphology of the study area is a domain of the Cameroon coastal plain with low altitudes $(40-120 \mathrm{~m})$. The Missole II area shows hills with flat and sharp summits and is deeply dissected by $\mathrm{V}$ and $\mathrm{U}$ shaped valleys 
of MBongo, Bongougou, Missolo and Bongo the main rivers of the area. According to the geological map of $\mathrm{SNH} / \mathrm{UD}$ report [12], the relative age of the Missole II sediments is Paleocene-Eocene corresponding to the N'Kapa Formation Figure 1.

The lithostratigraphy of Douala sub-basin is made of seven major Formations related to its geodynamic and sedimentary evolution [10-12]. 1) The synrift period represented by the Mundeck Formation (Aptian-Cenomanian) is discordant onto the Precambrian basement and consists of continental and fluvio-deltaic deposits, i.e., clays, coarse-grained sandstones, conglomerates. The postrift sequence includes; 2) the Logbadjeck Formation (Cenomanian-Campanian), discordant onto the Mundeck Formation and composed of micro conglomerates, sand, sandstone, limestone, and clay; 3) the Logbaba Formation (Maastrichtian), mainly composed of sandstone, sand and fossiliferous clay; 4) the N'kapa Formation (Paleocene-Eocene), rich in marl and clay with lenses of sand and fine to coarse-grained crumbly sandstone; 5) the Souellaba Formation (Oligocene) lying un- conformably on N'kapa deposits and characterized by marl deposits with some interstratified lenses and sand channels; 6) the Matanda Formation (Miocene), dominated by deltaic facies interstratified with volcanoclasties layers; and 7) the Wouri Formation (Plio-Pleistocene) which consists of gravelly and sandy deposits with a clayey or kaolinic matrix.

\section{Raw Materials and Experimental Methods}

The raw material used in this study comes from four representative clayey profiles of the Missole II area with three profiles of the interfluves along the Douala-Edéa road and one from the pit drilling on the lower slope of the valley. A geological survey shows different types of sediments with micro conglomerates, sandstones, fragments of ferruginous duricrusts and clays. Clayey layers are overlain upwards by sandstones or micro conglomerates, ferruginous duricrusts and sandy-clays, and occupy the lower part of the profiles. Four clayey facies identified with different mixed textures like sandy-clay, clayey-

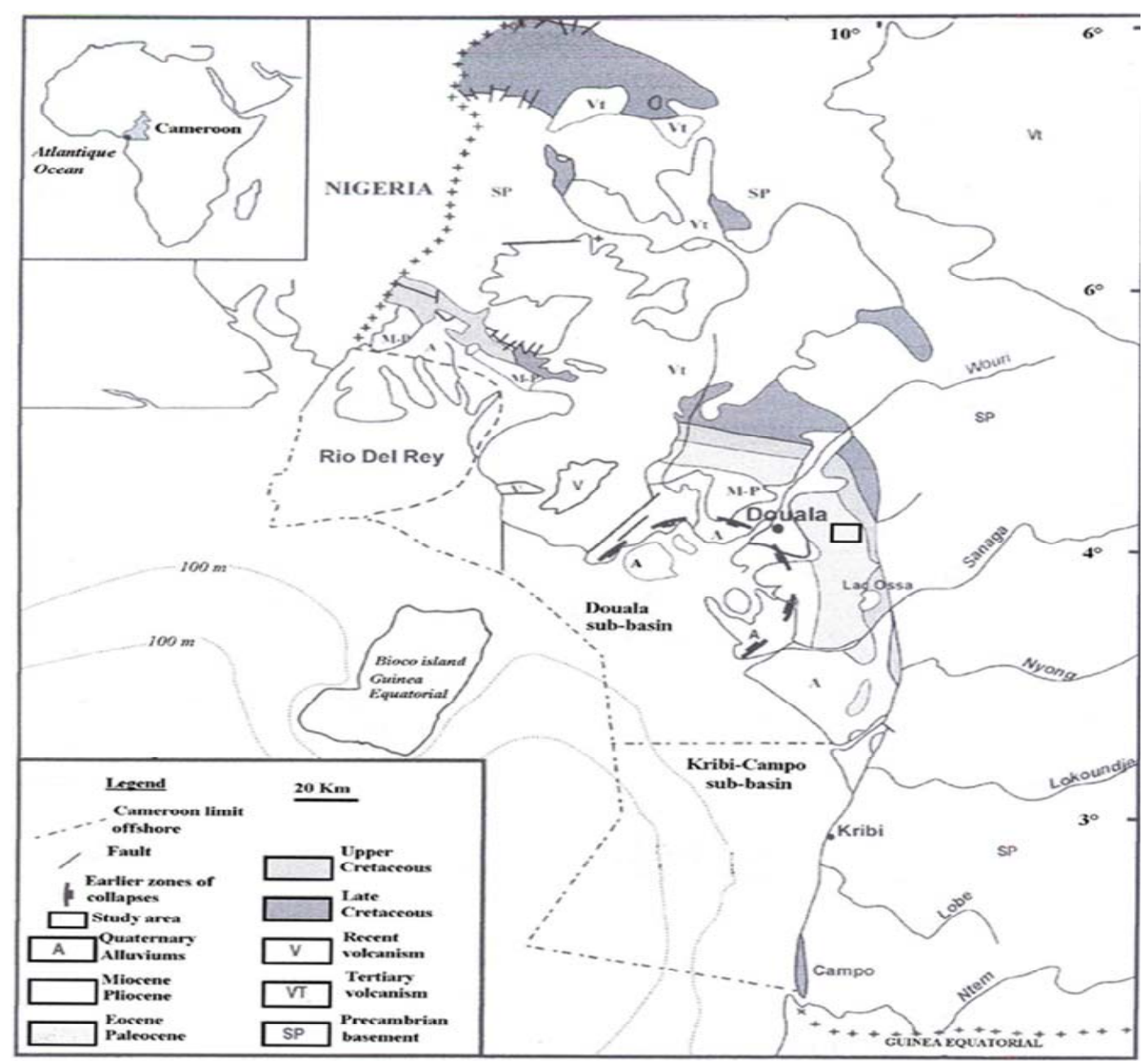

Figure 1. Geological sketch map of Cameroonian coastal basins (SNH/UD, 2005). 
silt and silty-clay are mainly of sedimentary origin [23, 24]. The average thickness of the exploitable layers is 2.5 $\mathrm{m}$. Two clayey samples collected from clay layer of each representative profile for mineralogical and chemical data are mixed to obtain average sample which served to realize the geotechnical analyses. A sufficient quantity of the single mixture of 2 to $3 \mathrm{~kg}$ of sediments is collected from a meter-long groove. The sample is analyzed for physical, mineralogy and chemistry.

The particle size distribution has been achieved in two steps: 1) a conventional sieving for the 63 to $2000 \mu \mathrm{m}$ fractions; 2) using a sedigraph 5000 in automatic procedure for clay and silt fractions. The liquid limit is measured by the method of the dish of Casagrande $(w L)$ and the plastic limit by the method of the roller (wP). The blue methylene value $(\mathrm{Vb})$ is determined on the total sample.

One hundred grams of each homogenized sample is grounded to -200 mesh $(0.075 \mathrm{~mm})$ in an agate mortar for chemical and XRD mineralogical study. Mineral identification is performed using a Setsys 2400 apparatus from SETARAM 85 equipped with a DSC 1500 heat system with Pt crucibles for thermal analysis, from room temperature up to $1100^{\circ} \mathrm{C}$ using a rate treatment of $10^{\circ} \mathrm{C} \cdot \mathrm{min}^{-1}$ and alumina heat treated at $1500^{\circ} \mathrm{C}$ serving as reference material. For XRD, a Brünker diffractometer D8 ADVANCE with a copper source $(\lambda=1.5489 \AA)$ is used on bulk and fine $(<2 \mu \mathrm{m})$ samples, working under $40 \mathrm{kV}$ and $40 \mathrm{~mA}$. The exposure time for qualitative analysis is $2 \mathrm{~h}$. Mineralogical phases are identified (JCPDS, 1998). Semi-quantitative analysis is performed [27]. For microscopic analysis, clay samples are examined with a scanning electron microscope (SEM) (Cambridge stereos can 200) coupled with an energy dispersive spectra microprobe (EDS). Homogenized powder of sediment sample is chemically analyzed for major and trace elements by ICP-AES after dissolution using acid digestion procedure with $\mathrm{HF}, \mathrm{HNO}_{3}$, and $\mathrm{HClO}_{4}$. Classification of the clayey materials is performed by Autret (1983) method [28,29]. This method differentiates lateritic materials to non lateritic materials. It is based on the ratio $\mathrm{S} / \mathrm{R}$ where, $\mathrm{S}$ is the ratio between $\mathrm{SiO}_{2}$ concentration and the molar mass and $\mathrm{R}$ the ratio between $\mathrm{Al}_{2} \mathrm{O}_{3}$ plus $\mathrm{Fe}_{2} \mathrm{O}_{3}$ concentrations and their molar mass. In fact, for true lateritic material $\mathrm{S} / \mathrm{R}$ is less than 1.33 , for lateritic rocks it is 1.33 to 2 , and for clay material it is more than 2 .

\section{Results}

\subsection{Geotechnical Characteristics}

The particle size distribution of the raw basic materials shows that the samples consist of 23 to $45 \mathrm{wt} . \%$ of sand, 17 to $33 \mathrm{wt} . \%$ of silts and 34 to $45 \mathrm{wt} . \%$ of clayey fractions. The geotechnical characteristics of the samples are reported in Table 1. These results are permitted to deduce that the class of these samples is in fine fractions [30]. The plasticity index (13.8\% to $21.6 \%)$ is varied between 12 and 25, and shows that these materials are averagely plastic [31]. This plasticity is presumably a consequence of the average content of clayey minerals and quartz. The methylene blue value $(0.4$ to $0.91 \mathrm{~g} / 100 \mathrm{~g})$ of the concerned materials, which is corroborated with the plasticity index, may suggest the absence of swelling clay minerals.

\subsection{Mineralogical Composition}

\subsubsection{DTA analysis}

Figure 2 represents the DTA analysis curves obtained for the raw materials $\mathrm{M} 2 \mathrm{P} 3$ and $\mathrm{M} 2 \mathrm{~A} 3$ at room temperature up to $1100^{\circ} \mathrm{C}$ using a rate treatment of $10^{\circ} \mathrm{C} \cdot \mathrm{min}^{-1}$. Differential scanning calorimetric (DSC) observed on these DTA analysis curves shows endothermic pheno-

Table 1. Geotechnical characteristics of the samples.

\begin{tabular}{|c|c|c|c|c|}
\hline \multirow{2}{*}{$\begin{array}{c}\begin{array}{c}\text { Geotechnical } \\
\text { characteristics }\end{array} \\
\text { Average samples }\end{array}$} & \multicolumn{4}{|c|}{ Results } \\
\hline & M2A2 & M2P3 & M2P4 & M2A3 \\
\hline Depth (cm) & $600-750$ & $700-800$ & $700-800$ & $50-150$ \\
\hline \multicolumn{5}{|c|}{ Particles size distribution (wt.\%) } \\
\hline Sand (2000 - $63 \mu \mathrm{m})$ & 45 & 31.3 & 44 & 22 \\
\hline Silts (63 - $2 \mu \mathrm{m})$ & 21 & 25.5 & 17 & 33 \\
\hline Clays $(<2 \mu \mathrm{m})$ & 34 & 43.2 & 39 & 45 \\
\hline \multicolumn{5}{|c|}{ Atterberg limits } \\
\hline Liquid limit, wL (\%) & 35.11 & 40.87 & 32.9 & 47.45 \\
\hline Plasticity limit, wP (\%) & 19.84 & 22.92 & 19.07 & 25.81 \\
\hline Plasticity index, PI (\%) & 15.27 & 17.95 & 13.83 & 21.64 \\
\hline $\begin{array}{l}\text { Blue methylene value of } \\
\text { the total sample }(\mathrm{g} / \mathbf{1 0 0 g})\end{array}$ & 0.4 & 0.82 & 0.7 & 0.91 \\
\hline
\end{tabular}

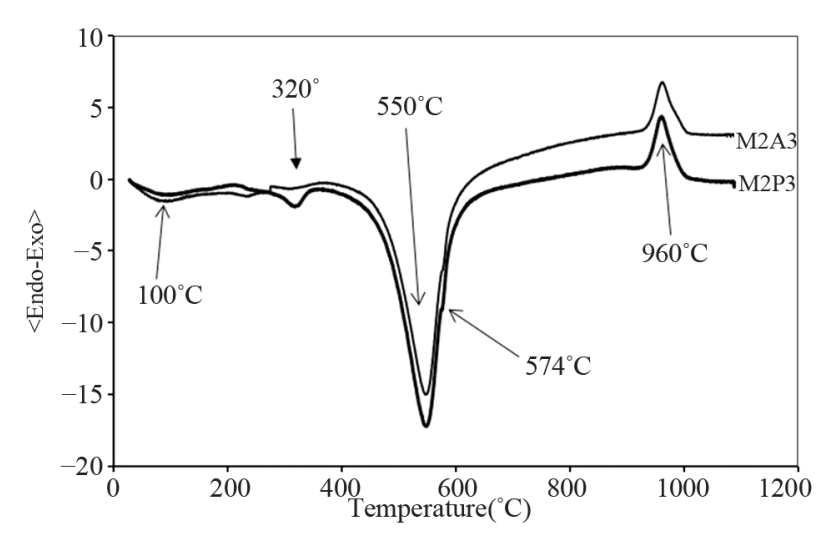

Figure 2. DTA curves of M2A3 and M2P3 materials for a heating rate of $10^{\circ} \mathrm{C} / \mathrm{min}$. 
menon towards $110^{\circ} \mathrm{C}$ associated to the physisorbed water and another endothermic phenomenon towards $320^{\circ} \mathrm{C}$ due to the dehydroxylation of goethite. A specific endothermic transformation at $400^{\circ} \mathrm{C}-600^{\circ} \mathrm{C}$ is due to the loss of structural hydroxyl groups of the kaolinite and an exothermic peak at $900^{\circ} \mathrm{C}-1000^{\circ} \mathrm{C}$ due to the structural reorganization of the metakaolinite $[32,33]$.

\subsubsection{X-Ray Diffraction}

The diffractograms of powder of the bulk samples ground until $<80 \mu \mathrm{m}$ revealed that clayey materials are kaolinitic and illitic and have permitted the detection of

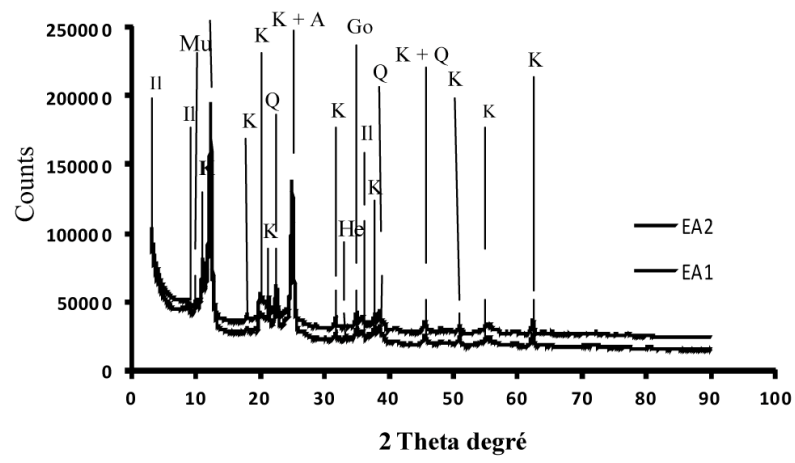

(a)

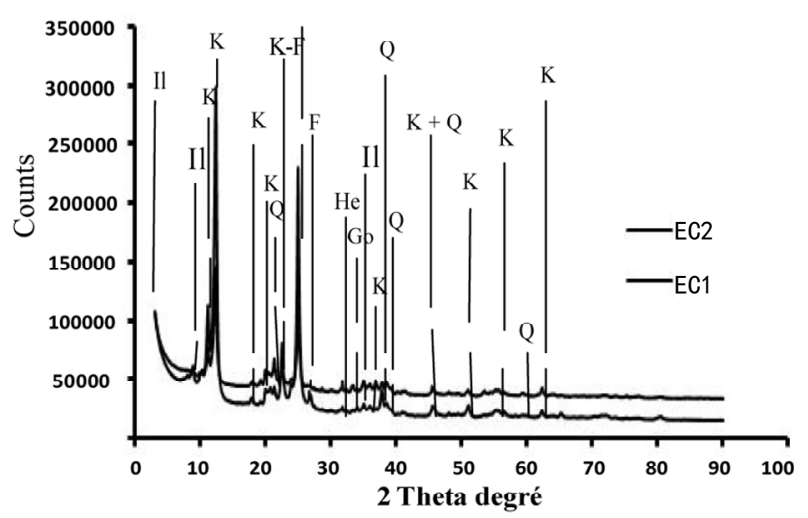

(c) the following mineral phases: kaolinite, quartz, illite, goethite, hematite and accessory feldspar-K and anatase [24]. These mineral phases were usually present in theclayey materials of the Douala sub-basin $[16,17,21]$.

The diffractograms of $<2 \mu \mathrm{m}$ fraction of Figure 3 also indicated the presence of the same mineral phases observed in the total samples with kaolinite, illite, quartz, goethite, hematite and accessory feldspar-K and anatase. Comparison of the minerals detected, these mineral phases are present in the fraction of the smaller and thicker granulometry.

The Table 2 gives the semi-quantitative mineralogical

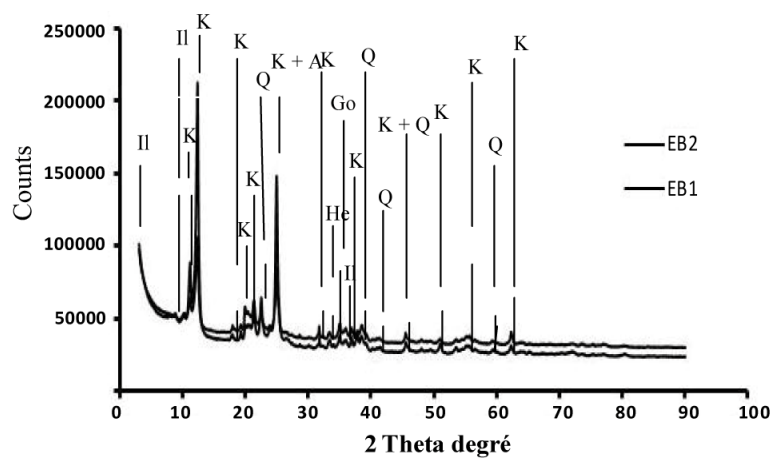

(b)

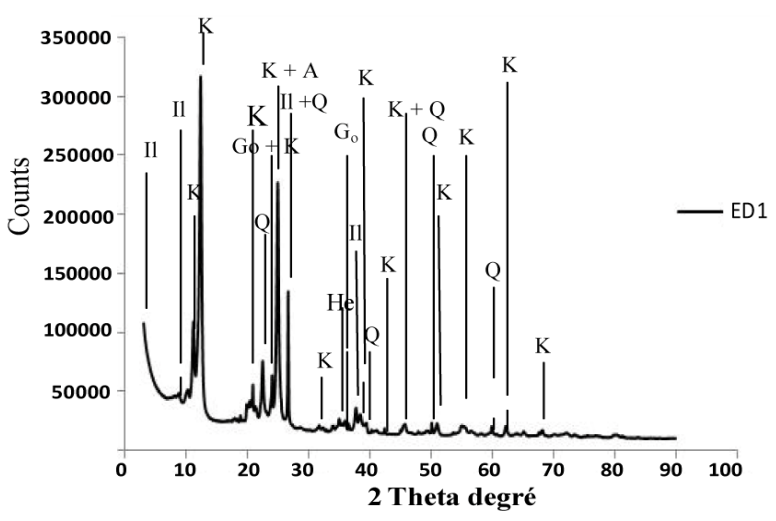

(d)

Figure 3. XRD patterns of <2 $\mathrm{mm}$ clay samples from Missolle II area of (a), (b), (c) and (d) profiles. A: Anatase; G: Goethite; He: Hematite; Il: Illite; K: Kaolinite; Q: Quartz; F: K-feldspar.

Table 2. Semi-quantitative mineralogical composition of the samples (wt.\%).

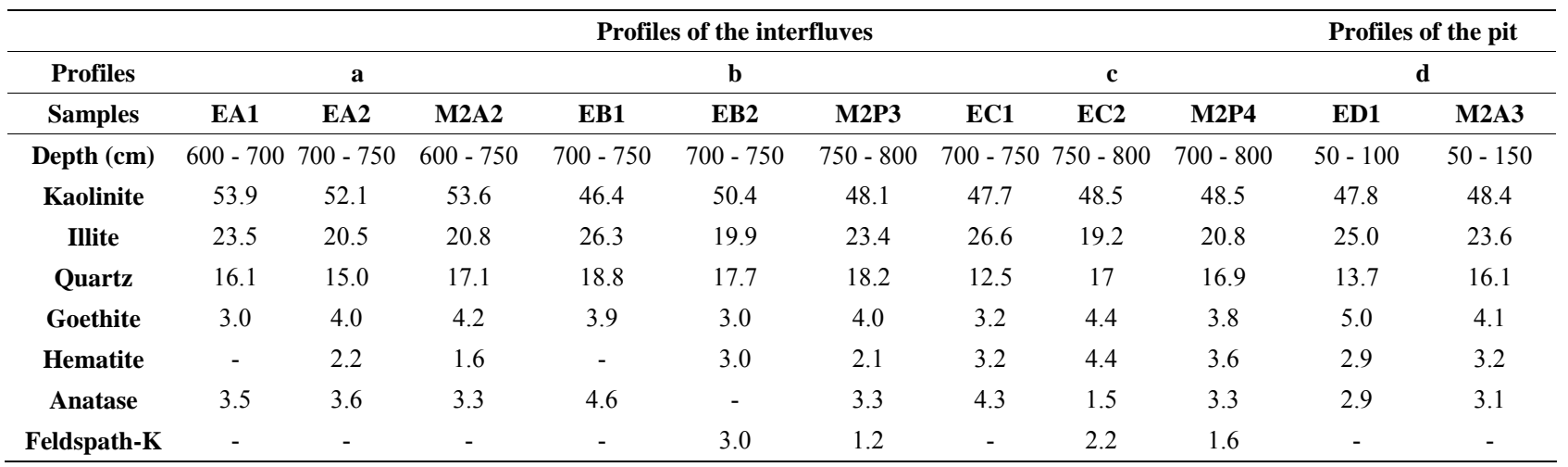


composition of the mineral phases of the samples. It reported an important proportion of kaolinite (46 to 56 wt.\%), appreciable amounts of illite (19 to $27 \mathrm{wt} . \%)$ and quartz (12 to 19 wt.\%), which are in relation with the value of the plasticity index (13.8 to $21.6 \%)$ and the methylene blue value $(0.8$ to $1.6 \mathrm{~g} / 100 \mathrm{~g})$. The amounts of the other mineral phases are respectively goethite (3 to 5 wt.\%), hematite (2 to $5 \mathrm{wt} \%$ ), anatase (1.5 to $5 \mathrm{wt} . \%$ ) and feldspar-K (2 to 3 wt.\%).

\subsubsection{Microscopic Analysis}

Figure 4 shows a SEM observation performed on samples of grey and mottled, with sandy-clay, silty-clay and clayey-silt texture. In clayey materials, piles of disordered kaolinites are observed with various sizes and irregular forms, which indicated that kaolinites of sedimentary clayey material of the Missole II area are poorly crystallized [34].

\subsection{Chemical Composition}

The chemical composition of the samples is given on Table 3. The results of the chemical analysis shows the presence of important amounts of $\mathrm{SiO}_{2}$ (52.87 to 63.11 wt.\%), associated with an appreciable amounts of $\mathrm{Al}_{2} \mathrm{O}_{3}$ (18.08 to 24.31 wt.\%) and $\mathrm{Fe}_{2} \mathrm{O}_{3}$ (3.28 to 11.45 wt.\%) and a small content of bases $(<2$ wt. $\%, \mathrm{CaO}+\mathrm{MgO}+$
$\mathrm{Na}_{2} \mathrm{O}+\mathrm{K}_{2} \mathrm{O}$ ).

These results show that quartz, alumino-silicates com-

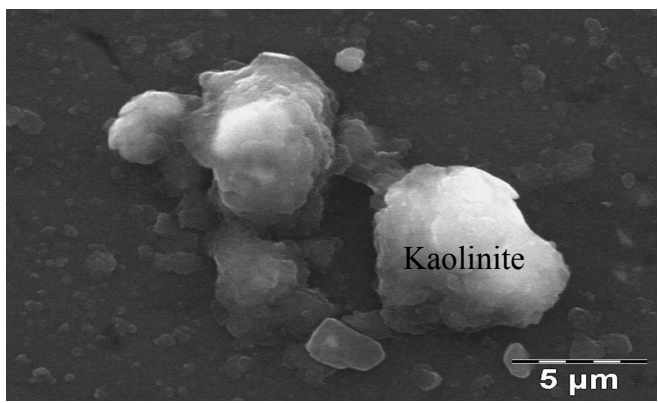

$\mathrm{M} 2 \mathrm{P} 3$

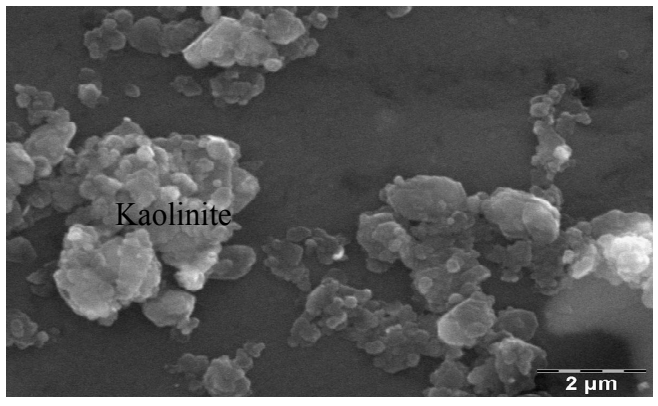

$\mathrm{M} 2 \mathrm{~A} 3$

Figure 4. SEM images of M2P3 and M2A3 clayey materials of Missole II.

Table 3. Chemical composition of the sample.

\begin{tabular}{|c|c|c|c|c|c|c|c|c|c|c|c|c|}
\hline \multirow{2}{*}{$\begin{array}{l}\text { Profiles } \\
\text { Samples }\end{array}$} & \multicolumn{10}{|c|}{ Profiles of the interfluves } & \multirow{2}{*}{\multicolumn{2}{|c|}{$\begin{array}{c}\text { Profiles of the pit } \\
\text { d }\end{array}$}} \\
\hline & & & $\mathbf{a}$ & & & $\mathbf{b}$ & & & c & & & \\
\hline Depth (cm) & & $600-700$ & $700-750$ & $600-750$ & $700-750$ & $700-750$ & $750-800$ & $700-750$ & $750-800$ & $700-800$ & $50-100$ & $50-150$ \\
\hline $\mathrm{SiO}_{2}$ & 0.01 & 63.11 & 56.85 & 58.01 & 54.97 & 57.24 & 56.23 & 52.87 & 54.02 & 54.08 & 63.1 & 62.84 \\
\hline $\mathrm{Al}_{2} \mathbf{O}_{3}$ & 0.01 & 18.94 & 24.31 & 23.06 & 22.16 & 19.1 & 20.87 & 23.24 & 20.59 & 21.01 & 18.08 & 18.61 \\
\hline $\mathrm{Fe}_{2} \mathrm{O}_{3}$ & 0.01 & 3.28 & 3.45 & 3.39 & 5.96 & 7.54 & 8.02 & 3.51 & 11.45 & 8.89 & 4.0 & 3.54 \\
\hline $\mathrm{CaO}$ & 0.01 & 0.04 & 0.02 & 0.02 & 0.02 & 0.2 & 0.02 & 0.02 & 0.02 & 0.02 & 0.02 & 0.02 \\
\hline MgO & 0.01 & 0.1 & 0.1 & 0.1 & 0.13 & 0.08 & 0.1 & 0.13 & 0.08 & 0.12 & 0.1 & 0.1 \\
\hline $\mathbf{K}_{2} \mathbf{O}$ & 0.01 & 0.43 & 0.4 & 0.49 & 0.77 & 0.21 & 0.3 & 0.47 & 0.47 & 0.47 & 0.6 & 0.7 \\
\hline $\mathrm{TiO}_{2}$ & 0.01 & 1.02 & 1.38 & 1.42 & 0.99 & 1.1 & 1.0 & 1.2 & 1.2 & 1.2 & 0.78 & 0.83 \\
\hline MnO & 0.01 & 0.01 & 0.01 & 0.01 & 0.01 & 0.01 & 0.01 & 0.01 & 0.01 & 0.01 & 0.01 & 0.01 \\
\hline $\mathbf{P}_{2} \mathbf{O}_{5}$ & 0.01 & 0.02 & 0.04 & 0.04 & 0.04 & 0.04 & 0.03 & 0.02 & 0.05 & 0.05 & 0.03 & 0.03 \\
\hline $\mathrm{Cr}_{2} \mathrm{O}_{3}$ & 0.01 & 0.01 & 0.01 & 0.01 & 0.01 & 0.02 & 0.01 & 0.01 & 0.02 & 0.01 & 0.01 & 0.01 \\
\hline LOI & & 13.02 & 13.12 & 13.29 & 14.21 & 13.85 & 13.21 & 17.38 & 11.81 & 14.01 & 14.4 & 12.34 \\
\hline Total & & 99.94 & 99.75 & 99.9 & 99.37 & 99.22 & 99.9 & 99.29 & 99.79 & 99.93 & 99.25 & 99.34 \\
\hline
\end{tabular}

DL: Detection limit; LOI: Loss on ignition. 
pounds and iron minerals are predominate in the samples. The weak content of oxide calcium or potassium has proven that the calcitic and potassic minerals like calcite or feldspar are absent or are in a weak proportion. With $\mathrm{S} / \mathrm{R}$ more than 2, the analyzed samples are clays [28].

\section{Discussion}

The particle size in this study revealed texture classes: silty-clay, clayey-silt and sandy-clay described in many deposits of the Douala sub-basin [17,21]. These classes characterized very sticky and plastic materials in accordance with some field characteristics such as smoothness, stickiness and plasticity [35]. Indeed, the fine particles and especially the very fine clay minerals determine the plasticity of an earthly material [32]. The plasticity index (13.8\% to $21.6 \%)$ of the above clayey samples is supported by the high amounts of fine particles (silt + clay) and fine clay minerals. The amount of clay fraction is used to determine the manufactured products as is shown in Table 4 [36]. However, particle size and plasticity index are amongst the main geotechnical characteristics used to determine a convenient choice of construction material. In this case, taking into account of the amounts of sand ( 22 to $44 \mathrm{wt} . \%$ ), fine particles notably the clay fractions (34 to $45 \mathrm{wt} \%$ ), and plasticity index, the Missole II clayey materials are convenient to the manufacturing of bricks, tiles and sandstones [37-39].

The mineralogical composition and geotechnical characteristics of a construction material must be known simultaneously in order to make a suitable choice for this raw basic material. It is well known that clay minerals have detrimental effects on the geotechnical properties; since some swelling clay minerals such as smectites absorb more water than the other (e.g. kaolinite). The volumetric shrinkage which increases with swelling clay minerals such as smectites constitutes an important parameter to take into account for civil public engineering $[29,40]$. The amount of clay minerals and especially swelling clay minerals contribute to the increasing of volumetric shrinkage and the swelling phenomena. Some authors joined the swelling potential and/or volumetric shrinkage to two parameters [36]. A first ordering is based on the plasticity index and the percentage of fine clayey

Table 4. Relation between particles size and type of ceramic product to realize (after Cere and Mazel, 1993).

\begin{tabular}{cc}
\hline$\phi<2 \mu \mathbf{m}($ wt. \%) & Ceramic products to realize \\
\hline $5-25$ & Full bricks \\
$25-35$ & Perforated bricks \\
$35-45$ & Hollow bricks, drains \\
$40-50$ & Tiles, hordes \\
\hline
\end{tabular}

fraction $(<2 \mu \mathrm{m}$ size). A second method proposes to use the liquid limit and the percentage of fine particles which size is less than $74 \mu \mathrm{m}$ [41]. In this case, the studied materials, which have plasticity index between $12 \%$ and $25 \%, 34$ and $45 \mathrm{wt} . \%$ of clayey fraction $(<2 \mu \mathrm{m}$ size $), 54$ and $78 \mathrm{wt} \%$ of fine fraction $(<80 \mu \mathrm{m}$ size $)$ and liquid limit between $32 \%$ and $47 \%$ are very low to moderate swelling materials as is indicated in Table 5. This observation is corroborated with the mineralogical composition which shows that fine fraction is mainly composed of kaolinite and few illites, as well as smectites are absent.

The geotechnical and mechanical characteristics of clayey materials are essentially depending on their chemical and mineralogical compositions as well as of the minerals distribution [37,39]. In this study, the clayey samples mainly constituted of poorly crystallized kaolinite (46 to 56 wt.\%), which is in agreement with the loss on ignition (12\% to $17 \%$ ), illite (19 to $27 \mathrm{wt} \%$ ) and quartz (12 to 19 wt.\%), are adequate for the composition of ceramic pastry [42] and for the manufacturing of bricks and tiles [14,37]. Also, clayey materials are siliceous $\left(\mathrm{SiO}_{2}>60 \mathrm{wt} . \%\right)$, with their alumina $\left(\mathrm{Al}_{2} \mathrm{O}_{3}\right)$ content less than $35 \mathrm{wt} \%$ and appreciable amount of iron ( $<10$ wt.\% with the exception of EC2 sample) is suitable for the manu- facturing of tiles and bricks [41]. However, the weakest amounts of bases $<2$ wt.\% (oxides of calcium, magne- sium, sodium and potassium) which are the smelting or cimentitious compound corroborated with the flexural strength less than $10 \mathrm{MPa}$ of the Missole II clayey material [25].

\section{Conclusions}

The following conclusions can be drawn out from the present work:

1) The geotechnical, mineralogical and chemical results show that the clayey materials of the Missole II, Douala sub-basin of Cameroon are mainly constituted of sand (23 to $45 \mathrm{wt} . \%$ ), silts (17 to $33 \mathrm{wt} . \%$ ) and clays (34 to $45 \mathrm{wt} . \%$ ) with plasticity index of $13.8 \%$ to $21.6 \%$.

2) Kaolinite, illite and quartz are the main minerals.

3) Clayey materials are also siliceous and aluminous, and have appreciable amount of iron in most clayey

Table 5. Swelling potential of soils according to their plasticity index, liquid limit and respectively their $<2$ and $<74$ $\mu \mathrm{m}$ fractions.

\begin{tabular}{ccccc}
\hline PI (\%) & $\mathbf{\%}<\mathbf{2} \boldsymbol{\mu m}$ & $\mathbf{\%}<\mathbf{7 4} \boldsymbol{\mu m}$ & $\mathbf{w L}(\mathbf{\%})$ & Swelling potential \\
\hline$>\mathbf{3 5}$ & $>95$ & $>95$ & $>60$ & Very high \\
$\mathbf{2 2}$ - $\mathbf{3 5}$ & $60-95$ & $60-95$ & $40-60$ & High \\
$\mathbf{1 8}-\mathbf{2 2}$ & $30-60$ & $30-60$ & $30-40$ & Moderate \\
$<\mathbf{1 8}$ & $<30$ & $<30$ & $<30$ & Low \\
\hline
\end{tabular}


samples $\left(\mathrm{Fe}_{2} \mathrm{O}_{3}\right.$ less than $\left.10 \mathrm{wt} \%\right)$.

4) Based on the obtained geotechnical, mineralogical and chemical results, and the literature data, the studied materials are suitable for the manufacturing of bricks, tiles and sandstones.

5) These clayey materials present poor mechanical characteristics (feeble flexural strength and great fragility) partly linked to the chemical and mineralogical nature fundamentally complex of natural clays.

\section{Acknowledgements}

The authors acknowledge the financial support of the University of Douala and the geochemical analysis of Geo Labs (Geoscience Laboratories) in Canada. Many thanks are also given to Professor David Smith, Director of the GEMH laboratory at ENSCI and Professor Gisèle Lecomte of Centre Européen de la Céramique, Limoges, France, and to all of their collaborators.

\section{REFERENCES}

[1] Y. C. Belmonte, "Stratigraphie du bassin sédimentaire du Cameroun," Proceeding on 2nd West African Micropaleontology Colloquium, Ibadan, 1-5 September 1966, pp. 7-24.

[2] M. E. Brownfield and R. R. Charpentier, "Geology and Total Petroleum Systems of the West-Central Coastal Province (7203) West Africa," USGS: Geological Survey Bulletin, 2006, 2207-B 52 p.

[3] E. Dartevelle and P. Brebion, "Mollusques fossiles du Crétacé de la Côte occidentale d'Afrique du Cameroun à l'Angola,"Annales du Musée Royal Congo Belge, Sciences Géologiques de Tervuren I-Gastéropodes, Vol. 8, No. 20, 1956, pp. 1-128.

[4] E. Dartevelle, S. Freinex and J. Sornay, "Mollusques fossiles du Crétacé de la Côte occidentale d'Afrique du Cameroun à l'Angola,"Annales du Musée Royal Congo Belge, Sciences Géologiques de Tervuren II-Lamellibranches, Vol. 8, No. 20, 1957, pp. 1-271.

[5] J. F. Dumort, "Identification par la Telédétection de l'Accident de la Sanaga (Cameroun)," Géodynamique, Vol. 1, No. 3, 1968, pp. 13-19.

[6] J. B. Meyers, B. R. Rosendahl and H. Groschel-Becker, "Deep Penetrating MCS Imaging of the Rift-to-Drift Transition Offshore Douala and North Gabon Basins West Africa," Marine Petrology Geology, Vol. 13, No. 7, 1996, pp. 791-835. doi:10.1016/0264-8172(96)00030-X

[7] D. Reyre, "Histoire géologique du bassin de Douala," In: D. Reyre, Ed., Symposium sur les Bassins Sédimentaires du Littoral Africain, Association du Service Géologique d'Afrique, IUGS, 1966, pp. 143-161.

[8] P. R. N. Ngaha, "Contribution à l'Etude Géologique, Stratigraphique et Structurale de la Bordure du Bassin Atlantique du Cameroun," Thèse 3e Cycle, Université de Yaoundé, 1984.

[9] P. Maurizot, A. Abessolo, J. L. Feybesse, V. Johana and
P. Lecomte, "Synthèse des Travaux de 1978 a' 1986," Rapport 85CM066, 1986.

[10] J. M. Regnoult, "Synthèse Géologique du Cameroun," D.M.G., Yaoundé, Cameroun, 1986.

[11] F. R. Nguene, S. Tamfu, J. P. Loule and C. Ngassa, "Paleoenvironments of the Douala and Kribi/Campo Subbasins in Cameroon, West African," Colloque de Géologie Africaine, Libreville, Recueil des Communications, Géologie Africaine, 6-8 May 1991, 1992, pp. 129-139.

[12] SNH/UD, "Stratigraphie Séquentielle et Tectonique des Dépôts Mésozoïques Synrifts du Bassin de Kribi/Campo," Rapport Non Publié, 2005.

[13] C. S. Manga, "Stratigraphy, Structure and Prospectivity of the Southern Onshore Douala Basin Cameroon-Central Africa," In: M. J. Ntamak-Nida, G. E. Ekodeck and M. Guiraud, Eds., Cameroon and Neighboring Basins in the Gulf of Guinea (Petroleum Geology tectonics Geophysics Paleontology and Hydrogeology), African Geoscience, 2008, pp. 13-37.

[14] P. M. Thibaut and P. Le Berre, "Recherche d'Argiles Pour Briques Dans la Région de Yaoundé, Douala et Edéa," Rapport 85CM065, 1985.

[15] D. Njopwouo, "Minéralogie et Physico-Chimie des Argiles de Bomkoul et de Balengou (Cameroun). Utilisation Dans la Polymérisation du Styrène et Dans le Renforcement du Caoutchouc Naturel," Thèse d'Etat, Faculté des Sciences, Université de Yaoundé, 1984.

[16] D. Njopwouo and R. Wandji, "Minéralogie de l'Argile Kaolinique de Bomkoul (Cameroun)," Revue de Sciences et Technique, Série des Sciences de la Terre, I 3-4, 1985, pp. 71-81.

[17] D. Njopwouo and S. Kong, "Minéralogie de la Fraction Fine des Matériaux Argileux de Bomkoul et de Balengou (Cameroun)," Annales de la Faculté des Sciences, Série des Sciences Chimiques, I 1-2, 1986, pp. 17-31.

[18] A. Elimbi and D. Njopwouo, "Firing Characteristics of Ceramics from the Bomkoul Kaolinite Clay Deposit (Cameroon)," Tile and Brick International, Vol. 18, No. 6, 2002, pp. 364-369.

[19] A. M. M. Mpondo, "Cartographie des Affleurements de la Localité de Bomkoul (Sous-Bassin de Douala),” Université de Douala, Mémoire, 2010.

[20] M. B. Mbog, "Etude Morphologique, Physico-Chimique et Minéralogique des Argiles de Bomkoul Dans le Sous-Bassin Sédimentaire de Douala-Cameroun," Université de Douala, Douala, 2010.

[21] G. F. Ngon Ngon, J. Etame, M. J. Ntamak-Nida, M. B. Mbog, A. M. Maliengoue Mpondo, M. Gérard, R. Yongue-Fouateu and P. Bilong, "Geological Study of Sedimentary Clayey Materials of the Bomkoul Area in the Douala Region (Douala Sub-Basin, Cameroon) for the Ceramic Industry," Comptes Rendus Geoscience, Vol. 344, No. 6, 2012, pp. 366-376. doi:10.1016/j.crte.2012.05.004

[22] W. Samba, "Etude Morphologique, Géotechnique et Minéralogique des Argiles de Missole 2 Dans le SousBassin de Douala-Cameroun," Université de Douala, Douala, 2010. 
[23] E. O. Logmo, "Etude Géologique, Minéralogique et Géochimique des Argiles de Missole II Dans le Sous-Bassin de Douala (Cameroun)," Université de Douala, Douala, 2012.

[24] G. F. Ngon Ngon, E. Bayiga, M. J. Ntamak-Nida, J. Etame, S. Noa Tang and R. Yongeu-Fouateu, "Trace Elements Geochemistry of Clay Deposits of Missole II from the Douala Sub-Basin in Cameroon (Central Africa): A Provenance Study," Sciences, Technologie et Développement, Vol. 13, No. 1, 2012, pp. 20-35.

[25] G. F. Ngon Ngon, G. L. Lecomte Nana, R. Yongue Fouateu, G. Lecomte and P. Bilong, "Physicochemical and Mechanical Characterisation of Ceramic Materials Obtained from a Mixture of Silica, Feldspars and Clay Material of the Douala Region in Cameroon (Central Africa)," Advances in Ceramic Science and Engineering (ACSE), Vol., 2, No. 1, 2013, pp. 23-31.

[26] R. Letouzey, "Atlas du Cameroun, Phytogéographie Camerounaise," Imprimerie Nationale Yaoundé, 1968.

[27] A. K. Chakravorty and D. K. Ghosh, "Kaolinite-Mullite Reaction Series: The Development and Significance of a Binary Aluminosilicate Phase," Journal of the American Ceramic Society, Vol. 74, No. 6, 1991, pp. 1401-1406. doi:10.1111/j.1151-2916.1991.tb04119.x

[28] P. Autret, "Latérites et Graveleux Latéritiques," Laboratoire Central des Ponts et Chaussées, 1983.

[29] M. Younoussa, "Etude Géotechnique, Chimique et Minéralogique de Matières Premières Argileuses et Latéritiques du Burkina Faso Améliorées aux Liants Hydrauliques: Application au Génie Civil (Bâtiment et Route)," Thèse, Université de Ouagadougou, 2008.

[30] NF P94-057, "Analyse Granulométrique des Sols. Méthode par Sédimentation," AFNOR, 1992.

[31] NF P94-051, "Détermination des Limites d'Atterberg," AFNOR, 1993.

[32] C. A. Jouenne, "Traité de Céramiques et Matériaux Mine- raux," Septima, Paris, 1990.

[33] S. Lee, Y. J. Kim and H. S. Moon, "Phase Transformation Sequence from Kaolinite to Mullite Investigated by an Energy-Filtering Transmission Electron Microscope," Journal of the American Ceramic Society, Vol. 82, No. 10, 1999 , pp. $2841-2848$ doi:10.1111/j.1151-2916.1999.tb02165.x

[34] M. W. Carty, "The Colloidal Nature of Kaolinite," The Bulletin of the American Ceramic Society, Vol. 78, 1999, pp. 72-76.

[35] E. A. Fitzpatrick, "Soils-Their Formation, Classification and Distribution," Longman, Berlin, 1983.

[36] L. Cere and F. Mazel, "Caractérisation d'Argiles," ENSCI Limoges, 1993

[37] Y. Beron and P. Le Berre, "Guide de Prospection des Matériaux," Manuels et Methodes du BRGM, No. 5, 1983.

[38] V. Rigassi, "Bloc de Terre Comprimée," Manuel de Prospection, Vol. 1, Craterre EAG, 1995.

[39] N. Française, "Sols: Reconnaissance et Essais. Description-Identification-Dénomination des Sols," XP P94-011, 1999.

[40] A. A. Al-Rawas and M. Qamarouddin, "Construction Problems of Engineering Structures Founded on Expansive Soils and Rocks in Northern Oman," Building and Environment, Vol. 33, No. 2-3, 1998, pp. 159-171.

[41] A. Djedid, A. Bekkouche and A. M. Aissa Mamoune, "Identification and Prediction of the Swelling Behavior of Some Soils from the Tlemcen Region of Algeria," Bulletin des Laboratoires des Ponts et Chaussées, Vol. 233 , 2001, pp. 69-77.

[42] O. Castelein, "Influence de la Vitesse du Traitement Thermique sur le Comportement d'un Kaolin: Application au Frottage Rapide," Thèse, Université de Limoges, 2000 . 